\title{
Tinjauan Yuridis Tentang Kedudukan Anak Angkat dalam Sistem Kewarisan Hukum Adat pada Suku Lembak (Studi Kasus Di Kelurahan Dusun Besar Kecamatan Singaran Pati Kota Bengkulu)
}

\section{Juridical Review on The Position Of Adopted Child In Inheritance System In Legal Custom Of Lembak Tribe (Case Study In Dusun Besar Sub-District Singaran Pati District Of Bengkulu City)}

Irlan

Universitas Muhammadiyah Bengkulu, email: Irlan001@gmail.com

\begin{abstract}
ABSTRAK
Keberadaan anak angkat itu diambil dari lingkungan asalnya dan dimasukkan ke dalam keluarga yang mengangkatnya menjadi anak angkat. Alasan pengangkatan anak pada umumnya adalah takut tidak mendapatkan keturunan, dan kedudukan anak angkat tersebut adalah sama dengan kedudukan anak kandung, dan hubungan kekeluargaan dengan orang tua anak dengan sendirinya putus secara adat. Rumusan Masalah, bagaimanakah proses pengangkatan anak, kedudukan anak angkat dan tinjauan secara yuridis berdasarkan Undang-Undang Nomor 23 Tahun 2002 tentang Perlindungan Anak pada adat suku suku Lembak di Kelurahan Dusun Besar Kecamatan Singaran Pati Kota Bengkulu. Metode penelitian, Penelitian ini dapat dikategorikan sebagai penelitian yang bersifat penelitian hukum sosiologis atau empiris. Hasil penelitian, Proses pengangkatan anak menurut adat suku lembak Kelurahan Dusun Besar Kecamatan Singaran Pati Kota Bengkulu, yaitu sebagai berikut : Tahap musyawarah, Proses pengangkatan Penyebab pengangkatan anak pada masyarakat suku lembak, yaitu : Mempertahankan keturunan. Tetapi proses pengangkatan anak tersebut tidak dilakukan melalui proses di Pengadilan Negeri, yaitu adanya penetapan dari hakim tentang kedudukan anak angkat itu.
\end{abstract}

Kata Kunci: Yuridis, Anak Angkat, dan Suku Lembak.

\begin{abstract}
The existence of the adopted child was taken from his home environment and put into a family that raised him into adopted child. The reason for adopting child generally is the fear of not getting offspring, and the position of the adopted child is the same as the position of the biological child, and the family relationship with the child's parents is
\end{abstract}


Tinjauan Yuridis Kedudukan Anak Angkat dalam Sistem Kewarisan Hukum Adapt

Pada Suku Lembak

automatically broken off by custom. Problem of this research was formulated as follow: how is the process of child adoption, the position of adopted child and judicial review based on Law No. 23 year 2002 about the Protection of Children in the Lembak tribe of Dusun Besar Sub-district Singaran District Bengkulu City. The method of this research can be categorized as the sociological or empirical legal research. The results showed that the processes of child adoption according to the custom of the Lembak tribe of Dusun Besar Sub-District Singaran Pati District Bengkulu City are as follows: Stage deliberation, and the process of appointment. The cause of child adoption in the Lembak tribe is: to maintain offspring. But the process of child adoption is not done through the process at the District Court that is the judge determination on the position of the adopted child.

\section{Kata Kunci : Juridical, Adopted Child, and Lembak Tribe.}

\section{PENDAHULUAN}

Dalam hukum waris adat, keturunan atau anak merupakan ahli waris yang utama untuk mewarisi seluruh harta kekayaan orang tuanya baik benda bergerak maupun benda tidak bergerak. Kedudukan anak yang menjadi ahli waris utama ini disebabkan karena antara anak dan orang tuanya itu mempunyai hubungan darah. Sehingga kerabat dekat lain, seperti paman, bibi akan terhalang untuk mendapatkan harta warisan. Dengan perkataan lain selain anak bukan ahli waris, hal ini merupakan ciri khas dalam hukum adat bahwa mereka cenderung untuk melindungi dan mensejahterahkan kerabatnya terutama keturunan mereka.

Memperhatikan dalam hukum adat yang cenderung mengutamakan kepentingan keturunannya (anak), hal ini tidak terlepas dari dasar pemikiran bahwa anak-anak inilah yang akan menjadi penerus keturunan kerabat atau keluarganya. Dalam hukum adat disamping anak kandung dikenal juga tentang anak angkat, dengan anak angkat itu sendiri status hukumnya dalam masyarakat adat tertentu disamakan dengan anak kandung.

Dalam masyarakat hukum adat Indonesia ketentuan mengenai anak sebagai ahli waris utama berbeda antara daerah yang satu dengan daerah yang lain disebabkan perbedaan sistem kekerabatan berkenaan dalam hal ini dikatakan oleh Dewi Wulansari.

"Pada masyarakat yang susunan matrilineal, keturunan garis ibu dipandang lebih penting dari garis keturunan bapak, sehingga menimbulkan hubungan atau pembauran kekeluargaan yang jauh lebih dekat ke pihak ibu, 
menyebabkan masalah kewarisan lebih banyak dari pihak bapak. Begitu juga sebaliknya dalam masyarakat yang mengakui garis keturunan bapak, maka hak-haknya pun lebih banyak dari keturunan ibu. ${ }^{\prime 1}$

Memperhatikan keterangan yang dikemukakan di atas, maka dapat dipahami bahwa walaupun dalam masyarakat hukum adat itu yang diutamakan sebagai ahli waris adalah anak-anak, tetapi anak-anak inipun adakalanya tidak mendapat harta warisan atau hanya mendapat sedikit. Hal ini tergantung dari sistem keturunan yang dipergunakan oleh masing-masing daerah, apakah matrilineal, patrilineal atau bilateral.

Pada umumnya kita melihat terdapat hubungan hukum yang didasarkan kepada hubungan kekeluargaan antara orang tua dengan anaknya. Juga kita melihat bahwa pada umumnya ada akibat-akibat hukum yang berhubungan dengan keturunan, bergandengan dengan ketinggalan leluhur. Akibat-akibat hukum ini tidak semua daerah sama, tetapi meskipun tidak sama, dalam kenyataannya masih terdapat satu pandangan pokok yang

${ }^{1}$ C. Dewi Wulansari, 2010. Hukum Adat Indonesia. Bandung, Rafika Aditama, halaman 37. sama terhadap masalah keturunan ini di seluruh daerah, yaitu bahwa keturunan adalah merupakan unsur yang esensial serta mutlak bagi suatu klan, suku ataupun kerabat yang menginginkan dirinya tidak punah yang menghendaki supaya ada generasi penerusnya. ${ }^{2}$

Mengangkat anak pada hakekatnya adalah suatu pengambilan anak orang lain ke dalam keluarga sendiri, sehingga antara orang yang mengangkat anak dengan anak yang diangkat timbul suatu hubungan kekeluargaan yang sama seperti antara orang tua dengan anak kandung. ${ }^{3}$

Kemudian dalam sistem kewarisan hukum adat, walaupun anak angkat tersebut tidak ada hubungan darah (kekeluargaan) dengan orang tua angkatnya, ia berposisi sama dengan anak kandung, hal ini berarti anak angkat mempunyai hak yang sama dengan anak kandung.

Oleh karena itu, apabila ada sesuatu klan, suku ataupun kerabat yang khawatir akan menghadapi kepunahan klan, suku ataupun kerabat, maka pada umumnya mereka melakukan adopsi (pengangkatan

\footnotetext{
${ }^{2}$ Soeroyo Wijoyodipuro,

${ }^{3}$ C. Dewi Wulansari, op.cit, halaman 44.
} 
Tinjauan Yuridis Kedudukan Anak Angkat dalam Sistem Kewarisan Hukum Adapt

Pada Suku Lembak

anak) untuk menghindari kepunahannya. ${ }^{4}$ Dalam melakukan pengangkatan anak tersebut pada umumnya diambil dari kerabat dekat sendiri, dan dalam kasus tertentu pengangkatan anak diambil dari luar klan.

Mencermati tentang pengangkatan anak sebagaimana yang telah dipaparkan di atas, maka pengangkatan anak itu mempunyai implikasi terhadap sistem kewarisan. Dalam sistem kewarisan, dengan terjadinya pengangkatan anak tersebut status hukumnya disamakan dengan anak kandung, sehingga anak angkat disamakan dengan anak kandung, seperti dikatakan oleh Muderis Zaini "kedudukan anak angkat yang proses pengangkatannya melalui upacara adat dan bantuan kepala adat adalah disamakan dengan anak kandung. sedangkan hubungan kekeluargaan dengan orang tuanya sendiri secara adat menjadi putus, seperti di daerah Gayo, Lampung, Pulau Nias dan Kalimantan. ${ }^{5}$ Kemudian implikasinya terhadap sosial kemasyarakat, sebagai anggota masyarakat pada utamanya mendapat hak-hak sosial seperti menghadiri upacara

\footnotetext{
${ }^{4}$ Ibid, halaman 35.

${ }^{5}$ Mudris Zaini, 2005, Adopsi Suatu Tinjauan Dari Tiga Sistem Hukum. Jakarta, Sinar Grafika, halaman 46.
}

adat. cara berpakaian tertentu diselipi penghormatan. ${ }^{6}$

Berdasarkan latar belakang yang telah dikemukakan di atas maka dalam penelitian ini dapat penulis rumuskan pokok masalahnya, yaitu :

1. Bagaimanakah proses pengangkatan anak menurut adat suku suku Lembak di Kelurahan Dusun Besar Kecamatan Singaran Pati Kota Bengkulu?

2. Bagaimanakah kedudukan anak angkat dalam sistem kewarisan adat suku Lembak di Kelurahan Dusun Besar Kecamatan Singaran Pati Kota Bengkulu?

3. Bagaimana tinjauan secara yuridis pengangkatan anak suku Lembak Kelurahan Dusun Besar Kecamatan Singaran Pati Kota Bengkulu berdasarkan Undang-Undang Nomor 23 Tahun 2002 tentang Perlindungan Anak?

\section{METODE PENELITIAN}

Penelitian ini dilaksanakan pada suku lembak yang berada di lingkungan Kelurahan Dusun Besar Kecamatan Singaran Pati Kota Bengkulu. Alasan penulis mengambil lokasi penelitian di

${ }^{6}$ Bushar Muhammad, 2001. Pokok-Pokok Hukum Adat. Jakarta, Pradnya Paramita, halaman 32. 
P-ISSN : 2599-1892

Volume : Vol. 1, No. 1, Januari 2018

Kelurahan Dusun Besar dikarenakan sebagian besar masyarakatnya merupakan penduduk asli.

Kemudian disamping itu juga di Kelurahan Dusun Besar ini masih ditemukan para tokoh adat yang memahami dan mengerti tentang proses pengangkatan anak, yang telah dilakukan secara turun temurun oleh nenek moyang dahulu, sehingga dari tokoh adat tersebut dapat digali sumber-sumber atau datadata tentang proses pengangkatan anak itu sendiri.

Penelitian ini dapat dikategorikan sebagai penelitian yang bersifat penelitian hukum sosiologis atau empiris, sedangkan pengertian penelitian hukum sosiologis atau empiris menurut Soerjono Soekamto adalah, "penelitian hukum yang dilakukan dengan cara meneliti data secara langsung di lapangan (masyarakat) untuk mendapatkan data primer". ${ }^{7}$

1. Data primer

Data ini diperoleh dari penelitian lapangan dengan mengadakan wawancara dengan responden sesuai dengan daftar pertanyaan yang telah disusun sebelumnya dan dikembangkan pada saat wawancara dengan membatasi pertanyaan sesuai dengan aspek masalah yang diteliti. Data primer ini dipergunakan untuk memperoleh keterangan yang benar dan dapat menjawab permasalahan yang ada.

2. Data sekunder

Data sekunder adalah data yang diperoleh melalui penelitian kepustakaan (libsrary research), dengan cara menelaah buku-buku, majalah-majalah, koran-koran, teoriteori hukum, dan peraturan-peraturan yang berhubungan dengan objek penelitian ini. Data ini digunakan untuk mendukung data primer.

Data yang telah dikelompokkan dan disusun secara sistematis, selanjutnya dianalisis secara kualitatif dengan menggunakan pendekatan induktif dan deduktif. Pendekatan induktif yaitu cara berpikir dengan menarik kesimpulan dari data-data yang bersifat khusus ke data yang bersifat umum. Pendekatan deduktif yaitu cara berpikir dengan menarik kesimpulan dari data yang bersifat umum ke data yang bersifat khusus. Berdasarkan analisis tersebut selanjutnya diuraikan secara sistematis sehingga pada akhirnya diperoleh jawaban permasalahan yang disusun dalam bentuk skripsi. 
Tinjauan Yuridis Kedudukan Anak Angkat dalam Sistem Kewarisan Hukum Adapt

Pada Suku Lembak

\section{PEMBAHASAN}

\section{Proses Pengangkatan Anak Menurut} Adat Suku Lembak Di Kelurahan Dusun Besar Kecamatan Singaran

\section{Pati Kota Bengkulu}

Secara umum terjadinya pengangkatan anak ini tidak terlepas dari orang tua tidak mempunyai anak, mereka merasa sangat kesepian dalam kehidupan berkeluarga tidak dikaruniai. Padahal keberadaan anak di masa kecil sebagai pelipur hati dan pada masa tua nanti anak tempat orang tua bergantung. Dengan adanya kondisi seperti ini, maka bagi pasangan suami istri yang tidak dikaruniai anak, mereka mengangkat anak.

Kemudian dalam

proses pengangkatan anak yang dilaksanakan di Kelurahan Dusun Besar Kecamatan Singaran Pati Kota Bengkulu ada beberapa tahap yang perlu dilakukan, yaitu :

\section{Tahap Musyawarah}

Adapun tahap musyawarah ini dilakukan menjelang pengangkatan anak, dimana pasangan suami istri ini mendatangi tempat kediaman calon anak angkat. Dalam tahap musyawarah ini pihak calon orang tua angkat yang akan menemui pihak keluarga calon anak angkat, yaitu suami istri yang akan mengangkat anak, dan kerabat dekat. Kemudian berkenaan dengan waktu untuk mendatangi rumah keluarga calon anak angkat, biasanya dilakukan pada malam hari setelah selesai pelaksanaan shalat maghrib dengan membawa makanan ringan ala kadarnya, seperti :

a. Lemang, yang terbuat dari beras ketan dan santan kelapa

b. Dodol

C. Bajik, yang terbuat dari beras ketan, gula merah dan santan kelapa. ${ }^{8}$

Berkenaan dengan isi pokok dalam pembicaraan tahap musyawarah ini, diungkapkan oleh Bayumi Alamsyah :

Tata cara pengangkatan anak dalam tahap musyawarah ini, pembicaraan yang diawali oleh pihak calon orang tua angkat, untuk mengetahui apakah keluarga besar dari calon anak angkat ini setuju atau bersedia, apabila anaknya akan diangkat anak oleh suami istri yang datang tersebut. Apabila pihak keluarga yang akan dijadikan anak angkat itu setuju, maka ditetapkan hari, tanggal dan bulan untuk

8 Bayumi Alamsyah, Tokoh Adat, wawancara, tanggal 23 Mei 2015. 
diadakan acara proses pengangkatan anak. Sebaliknya apabila keluarga calon anak angkat itu menolak maka calon orang tua angkat akan mengucapkan kata maaf atas kedatangannya, yang kemungkinan telah mengganggu ketenangan pihak tuan rumah. ${ }^{9}$

Pernyataan yang sama dikatakan oleh Zulkifli :

"Pembicaraan yang perlu disampaikan antara pihak yang akan mengangkat anak dan yang mempunyai anak ini, sebetulnya tidak terlalu rumit dan memakan waktu yang lama. Hal ini dikarenakan sebelum terjadinya kelahiran anak atau sebelum pihak yang akan mengangkat anak secara pribadi tanpa melibatkan orang lain telah dilakukan pembicaraan tentang akan mengangkat anak tersebut. Tetapi dalam proses musyawarah adat ini hanya secara formal saja agar orang lain akan mengetahui pengangkatan anak tersebut, yaitu mengulangi pembicaraan untuk mengangkat anak yang sudah disetujui sebelumnya". ${ }^{10}$

\section{Proses Pengangkatan Anak}

Setelah dari tahap musyawarah ada pertanda baik dari pihak keluarga calon anak angkat, dimana keluarganya menyetujui diadakan pengangkatan anak, maka setelah

9 Bayumi Alamsyah, Tokoh Adat, wawancara, tanggal 23 Mei 2015.

10 Zulkifli, Tokoh Masyarakat, wawancara, tanggal 23 Mei 2015. hari, tanggal dan bulan sebagaimana yang disepakati pada tahap musyawarah itu tiba, diadakanlah acara tahap pengangkatan anak.

Apabila tokoh adat dan pemuka masyarakat dan undangan telah hadir semua di dalam ruangan atau di sekitar tempat proses pengangkatan anak, maka diadakan proses pengangkatan anak. Adapun inti dari proses pengangkatan anak yaitu :

a. Kata sambutan dari pemuka atau tokoh masyarakat bahwa pada hari ini akan diadakan upacara pengangkatan anak, oleh pasangan suami istri dan proses musyawarahnya telah berlangsung beberapa waktu yang lalu.

b. Selanjutnya acara diserahkan kepada tokoh adat, dan inti dari acara tersebut adalah bahwa antara orang tua angkat dan anak angkat telah terikat dalam satu keluarga besar orang tua angkatnya. Sejak saat itu anak angkat ini akan menetap untuk selamanya di lingkungan keluarga orang tua angkatnya.

c. Anak angkat merupakan ahli waris dari orang tua angkatnya, dengan arti kata hak milik orang tua angkatnya, pada suatu saat nanti 
Tinjauan Yuridis Kedudukan Anak Angkat dalam Sistem Kewarisan Hukum Adapt

Pada Suku Lembak

akan menjadi hak miliknya secara mutlak. Apabila orang tua angkatnya ada anak kandung, maka harta orang tuanya itu akan dibagi dua antara anak kandung dan anak angkat.

d. Kemudian setelah proses pengangkatan itu selesai, dan telah diumumkan melalui pengurus suara oleh tokoh adat, tuan rumah (orang tua angkat) telah menyiapkan jamuan makan siang untuk dimakan oleh seluruh undangan. Adapun jamuan itu biasanya memotong ayam dan beberapa ekor kambing. ${ }^{11}$

Faktor Penyebab Pengangkatan Anak

Sebelum penulis memaparkan tentang faktor penyebab pengangkatan anak di Kelurahan Dusun Besar Kecamatan Singaran Pati Kota Bengkulu, maka terlebih dahulu akan penulis kemukakan tentang pengertian pengangkatan anak menurut masyarakat Kelurahan Dusun Besar Kecamatan Singaran Pati Kota Bengkulu, dalam hal ini dikemukakan oleh Sartoni, anak angkat adalah anak orang lain yang dijadikan sebagai anak sendiri dan berperan seperti

11 Samiruddin, Tokoh Adat, wawancara, tanggal 24 Mei 2015. dijadikan sebagai anak sendiri dan berperan seperti anak kandung, dan pengangkatan anak ini melalui proses adat, kemudian seluruh harta kekayaan orang tua angkatnya menjadi milik anak angkat. $^{12}$

Berdasarkan pengertian yang telah dikemukakan di atas, maka dapat dipahami bahwa pengertian pengangkatan anak adalah suatu proses memasukkan anak orang lain ke dalam keluarga yang mengangkatnya, dimana status dan peranannya sama dengan anak kandung. Jadi tujuan pengangkatan anak dalam masyarakat Kelurahan Dusun Besar Kecamatan Singaran Pati Kota Bengkulu ini, bukan hanya sekedar memberikan kasih sayang dan membantu biaya hidup terhadap anak angkat tersebut, tetapi kedudukannya dalam masyarakat dan keluarga sama dengan anak kandung.

Kemudian berkenaan dengan faktor penyebab terjadinya pengangkatan anak pada suku lembak di Kelurahan Dusun Besar Kecamatan Singaran Pati Kota Bengkulu, ada beberapa faktor, antara lain :

\section{Mempertahankan Keturunan}

${ }^{12}$ Sartoni, Pemuka Masyarakat, wawancara, tanggal 24 Mei 2015. 
Setiap perkawinan tidak dapat dipandang lepas dari pada kemungkinan mendapatkan anak, namun demikian tujuan utama dari sebuah perkawinan bukanlah sekedar hanya untuk mendapatkan anak. Melainkan untuk hidup bersama, akan tetapi suatu perkawinan dapat dibilang belum sempurna apabila suami isteri tidak dikaruniai keturunan anak. ${ }^{13}$

Demikian juga halnya di masyarakat lembak Kelurahan Dusun Besar Kecamatan Singaran Pati Kota Bengkulu, apabila pasangan suami isteri tidak mempunyai anak, maka mereka akan mengangkat anak. Dalam hal ini ditegaskan oleh Ahmad Kusnadi. Apabila suami isteri itu telah lama hidup berumah tangga (misalnya lima tahun) tetapi tidak mempunyai anak, maka suami isteri tersebut akan mengangkat anak, baik kepada kerabatnya sendiri maupun kepada orang lain. Sedangkan keberadaan anak angkat itu sama dengan kedudukan anak kandung. ${ }^{14}$

Kemudian menurut Abu Bakar, jika suami isteri tidak mempunyai anak

13 Wirjono Prodjodikoro, 1991. Hukum Perkawinan Di Indonesia. Bandung, Sumur, halaman 90.

14 Ahmad Kusnadi, Pemuka Masyarakat, wawancara, tanggal 25 Mei 2015. sedangkan masa perkawinan mereka telah lama berlangsung tetapi tidak mempunyai anak, maka suami isteri tersebut akan melakukan pengangkatan anak. Kemudian keberadaan anak angkat itu sama dengan status anak kandung. ${ }^{15}$

Hal senada juga diungkapkan oleh Zulkifli, memang bagi suami isteri yang tidak mempunyai anak akan merasa khawatir, karena tidak ada yang akan melangsungkan keturunan mereka di kemudian hari. Oleh karena itu bagi pasangan suami isteri yang tidak mempunyai keturunan, akan melakukan pengangkatan anak, agar keturunan mereka tidak terputus atau punah. ${ }^{16}$

\section{Diharapkan Anak Angkat Dapat} Menolong Orang Tua Angkatnya Di Hari Tua

Berkenaan dengan faktor penyebab pengangkatan anak ini, dalam kasus tertentu ada yang melakukan pengangkatan anak disebabkan untuk memelihara dirinya di hari tua nanti. Sebagaimana dijelaskan oleh Samirudin, adapun dilakukannva pengangkatan anak oleh

15 Abu Bakar, Tokoh Adat, wawancara, tanggal 25 Mei 2015.

${ }^{16}$ Zulkifli, Pemuka Masyarakat, wawancara, tanggal 25 Mei 2015. 
Tinjauan Yuridis Kedudukan Anak Angkat dalam Sistem Kewarisan Hukum Adapt

Pada Suku Lembak

pasangan suami isteri yang tidak mempunyai anak, dimaksudkan agar di hari tua mereka ada yang mengurus atau menolong diri mereka, sehingga mereka tidak akan terlantar dan tidak menderita. ${ }^{17}$

Kemudian hal senada juga dikatakan oleh Ahmad Kusnadi, dalam proses kehidupan bahwa keberadaan manusia itu lambat laun akan mengalami kurangnya kekuatan dalam diri dan juga sering sakit-sakitan. Dengan adanya kondisi seperti ini bagi individu yang mempunyai anak tidak menjadi persoalan karena ada yang akan mengurusnya, tetapi bagi suami isteri yang tidak mempunyai anak tentu akan menjadi kesulitan. Oleh karena itu bagi suami isteri yang tidak mempunyai anak, melakukan pengangkatan anak. ${ }^{18}$

Dari keterangan di atas, maka dapat dipahami bahwa memang secara alami siklus kehidupan manusia itu, mulai dari masa bayi, anak-anak, remaja, dewasa dan kakek nenek (sudah tua renta). Dalam kondisi kehidupan manusia sudah menjadi

17 Samirudin, Pemuka Masyarakat, wawancara, tanggal 25 Mei 2015.

18 Ahmad Kusnadi, Pemuka Masyarakat, wawancara, tanggal 25 Mei 2015. kakek nenek (telah uzur), maka ada sebagian keperluan mereka itu memerlukan bantuan orang lain. Oleh karena itu dengan adanya kondisi seperti ini bagi pasangan suami isteri yang tidak mempunyai keturunan. Akan melakukan pengangkatan anak mengurus diri mereka pada saat sudah tidak kuat lagi atau sudah uzur.

\section{Karena Hanya Mempunyai Anak Tunggal}

Berdasarkan hasil penelitian yang penulis lakukan di daerah penelitian dapat diketahui bahwa ada kasus pengangkatan anak, dikarenakan pasangan suami isteri tersebut hanya mempunyai anak perempuan tunggal. Berkenaan dengan hal ini dikatakan oleh Abu Bakar. Pada umumnya pasangan suami isteri di daerah ini mempunyai anak lebih dari dua orang dan bagi pasangan suami isteri hanya mempunyai anak tunggal, biasanya akan mengangkat anak. Terutama jika mereka hanya mempunyai anak perempuan tunggal, maka pasangan suami isteri itu akan mengangkat anak laki-laki, pada waktu anak sudah besar nanti dapat membantu orang tuanya 
mengurus harta dan kepentingan orang tua angkat yang lainnya. ${ }^{19}$

Kemudian di lain pihak dikemukakan oleh Zulkifli, di daerah ini sebagian besar mata pencaharian kedudukannya adalah sebagai petani, pedagang, untuk mengelola pertanian tentu saja dibutuhkan tenaga keija yang banyak. Oleh karena itu bagi pasangan suami isteri hanya mempunyai anak tunggal, akan mengangkat anak terutama anak lakilaki, hal ini diharapkan pada waktu anak tersebut besar nanti dapat membantu orang tua angkatnya mengelola dan mengawasi lahan pertanian. ${ }^{20}$

Dari keterangan yang telah dikemukakan di atas, dapat dipahami bahwa besarnya jumlah anggota keluarga di daerah penelitian ini sangat diharapkan oleh pasangan suami isteri. Hal ini tidak terlepas dari mata pencaharian sebagian masyarakatnya adalah petani dan pedagang tentu saja keberadaan tenaga kerja merupakan hal yang terpenting untuk mengerjakan lahan pertanian tersebut. Oleh karena itu bagi pasangan suami isteri yang hanya mempunyai anak tunggal, biasanya akan mengangkat anak, disamping untuk mengurus dan mengelola lahan pertanian, juga tidak merasa kesepian jika anak kandungnya akan pergi atau merantau ke daerah lain, misalnya melanjutkan pendidikan atau setelah kawin mengikuti suami atau isteri.

4. Sebagai Pemancing Bagi Suami Isteri Yang Tidak Mempunyai Anak Untuk Mendapatkan Anak Kandung

Sebagaimana telah disinggung pada pembahasan terdahulu bahwa perkawinan itu dapat dibilang belum sempurna apabila suami isteri tidak dikaruniai keturunan atau anak. Oleh karena itu banyak sekali usaha yang dilakukan oleh pasangan suami isteri yang telah lama kawin tetapi belum dikaruniai anak, disamping melakukan pengobatan dengan dokter ahli kandungan dan kebidanan, pengobatan alternatif, bahkan mengambil anak sebagai pemancing agar pasangan suami isteri tersebut mendapatkan anak. ${ }^{21}$

19 Abu Bakar, Tokoh Adat, wawancara, tanggal 26 Mei 2015.

${ }^{20}$ Zulkifli, Pemuka Masyarakat, wawancara, tanggal 26 Mei 2015.

21 Bushar Muhammad, 1991. Pokok-Pokok Hukum Pidana. Jakarta, Pradnya Paramita, halaman 52. 
Tinjauan Yuridis Kedudukan Anak Angkat dalam Sistem Kewarisan Hukum Adapt

Pada Suku Lembak

Demikian juga halnya di masyarakat suku lembak Kelurahan Dusun Besar Kecamatan Singaran Pati Kota Bengkulu ini, pengangkatan anak yang dilakukan oleh pasangan suami isteri yang belum mempunyai anak, sebagai pemancing agar mereka diberikan anak. Sebagaimana dikatakan oleh Samirudin, pada dasarnya harapan untuk memperoleh anak bagi pasangan suami isteri sangat diharapkan, sehingga bermacam-macam usaha mereka lakukan seperti berobat ke dokter ahli bahkan mengangkat anak sebagai pemancing agar memperoleh anak. ${ }^{22}$

Kemudian hal senada juga dikemukakan Zulkifli, apabila pasangan suami isteri telah lama kawin tetapi belum juga dikaruniai anak, biasanya akan mengangkat anak sebagai pemancing untuk mendapatkan anak kandung, seperti yang saya lakukan mengangkat seorang anak. Walaupun anak angkat tersebut hanya sebagai pemancing pasangan suami isteri untuk mendapatkan anak, tetapi kedudukan

22 Samirudin, Pemuka Masyarakat, wawancara, tanggal 27 Mei 2015. anak angkat tersebut sama dengan anak kandung. ${ }^{23}$

\section{Karena Tidak Mempunyai Anak Laki-Laki}

Sebagaimana telah disinggung pada pembahasan terdahulu bahwa masyarakat suku lembak Kelurahan Dusun Besar, apabila terjadi perkawinan, maka isteri akan menetap dan mengabdi di lingkungan keluarga suaminya. Dengan adanya kondisi seperti ini, hukum adat memberikan solusinya yaitu keluarga yang semua anaknya perempuan dapat melakukan pengangkatan anak, untuk menggantikan kedudukan anak perempuan dalam keluarga tersebut.

Dalam masyarakat suku lembak Kelurahan Dusun Besar ini, kedudukan anak laki-laki memegang peranan yang penting dalam sebuah keluarga yaitu sebagai kepala keluarga dan pemimpin dalam rumah tangga. Berkenaan dengan hal ini dijelaskan oleh Ahmad Kusnadi.

"Kedudukan anak laki-laki dalam masyarakat suku lembak Kelurahan Dusun Besar ini, merupakan pengambil keputusan dan sekaligus sebagai kepala keluarga dan juga mengganti posisi orang tuanya dalam masyarakat. Oleh karena itu jika ia berkeluarga nanti, maka isterinya yang

${ }^{23}$ Zulkifli, Pemuka Masyarakat, wawancara, tanggal 27 Mei 2015. 


\section{P-ISSN : 2599-1892}

Volume : Vol. 1, No. 1, Januari 2018

akan ikut dan mengabdi di lingkungan suami. ${ }^{\prime \prime 24}$

Dengan adanya sistem perkawinan seperti disebutkan di atas, maka bagi masyarakat yang tidak mempunyai anak laki-laki, ada dua pilihan agar keluarganya tidak punah/ habis. Dalam hal ini dijelaskan oleh Abu Bakar.

Apabila dalam satu keluarga itu tidak mempunyai anak laki-laki atau tidak mempunyai anak sama sekali, maka ada dua pilihan yang harus ditempuh yaitu:

a. Jika dalam suatu keluarga itu hanya mempunyai anak perempuan maka anak perempuan tersebut akan dikawinkan secara ambil anak, jadi pihak suami yang akan menetap di lingkungan keluarga isterinya. Tetapi hal ini sulit untuk melaksanakan, karena pihak laki-laki pada umumnya tidak mau kawin ambil anak. Karena jika anak laki-laki kawin ambil anak, maka keluarga laki-laki tersebut akan dianggap hina

24 Ahmad Kusnadi, Pemuka Masyarakat, wawancara, tanggal 27 Mei 2015. dan mereka merasa malu pada masyarakat.

b. Kemungkinan kedua mereka akan melakukan pengangkatan anak, yaitu mengangkat anak tersebut diutamakan mengangkat anak laki-laki untuk menggantikan posisi anak kandung orang tua angkatnya. ${ }^{25}$

\section{Kedudukan Anak Angkat Dalam} Sistem Kewarisan Adat Suku Lembak Di Kelurahan Dusun Besar Kecamatan Singaran Pati Kota Bengkulu

Dengan dilaksanakannya proses pengangkatan anak pada masyarakat suku lembak Kelurahan Dusun Besar Kecamatan Singaran Pati Kota Bengkulu, maka kedudukan anak angkat itu akan mempunyai hak-hak dalam hukum waris adat. Dengan perkataan lain kedudukan anak angkat tersebut merupakan salah satu ahli waris dalam lingkungan keluarga orang tua angkatnya. Dalam hal ini dikemukakan oleh Samirudin :

"Dengan terjadinya proses pengangkatan anak yang dilaksanakan melalui musyawarah adat, maka disini ada dua macam status hukum yang timbul, yaitu pertama kedudukan anak status

25 Abu Bakar, Tokoh Adat, wawancara, tanggal 27 Mei 2015. 
Tinjauan Yuridis Kedudukan Anak Angkat dalam Sistem Kewarisan Hukum Adapt

Pada Suku Lembak

hukumnya sama dengan anak dalam segala hal, dan kedua anak angkat menjadi salah satu ahli waris atas harta kekayaan orang tua angkatnya, dan harta orang tua angkatnya beralih kepada anak angkat pada saat orang tua angkatnya meninggal dunia". ${ }^{26}$

Hal yang sama dijelaskan oleh Sartoni :

"Adapun akibat dari proses pengangkatan anak melalui musyawarah adat, yang melibatkan tokoh adat, pemuka masyarakat dan warga masyarakat pada suku lembak Kelurahan Dusun Besar Kecamatan Singaran Pati Kota Bengkulu ini, adalah kedudukan anak angkat merupakan salah satu ahli waris dalam lingkungan keluarga orang tua angkatnya, yang berupa kebun, sawah, tanah pekarangan, rumah dan berbagai perhiasan terbuat dari emas". ${ }^{27}$

Hal senada dikemukakan oleh Bayumi Alamsyah :

"Akibat dari pengangkatan anak dalam masyarakat suku lembak menurut hukum adatnya, maka anak angkat merupakan salah satu ahli waris atau ahli waris tunggal dalam lingkungan keluarga orang tua angkatnya. Sedangkan harta warisan yang dimiliki berupa sawah, kebun, tanah pekarangan, hewan ternak, perhiasan dari emas". ${ }^{28}$

26 Samirudin, Pemuka Masyarakat, wawancara, tanggal 27 Mei 2015.

${ }^{27}$ Sartoni, Pemuka Masyarakat, wawancara, tanggal 27 Mei 2015.

28 Bayumi Alamsyah, Tokoh Adat, wawancara, tanggal 27 Mei 2015.
A. Dampak Pengangkatan Anak

Terhadap Sistem Kekerabatan (Kekeluargaan)

1. Terjadinya Perubahan Status Anak

Dalam masyarakat suku lembak ini sistem perkawinannya adalah jujur atau pihak laki-laki akan memenuhi ketentuan adat dan konsekuensinya, pihak perempuan akan bertempat tinggal dalam lingkungan keluarga suaminya. Jadi bagi mereka yang anaknya semua perempuan, setelah perkawinan berlangsung akan menetap untuk selamanya di lingkungan keluarga suami, sehingga orang tuanya akan hidup tanpa anak dan cucu yang menemani mereka di masa hari tua. Dengan adanya kondisi seperti ini, maka salah satu cara yang mereka lakukan adalah mengangkat anak.

\section{Berpindah Kekerabatan Dalam}

\section{Keluarga Orang Tua Angkat}

Sebagaimana telah dikemukakan di atas, bahwa dengan terjadinya pengangkatan anak, maka kedudukan anak angkat disamakan dengan anak kandung tentang hak dan kewajibannya. Hal ini berarti setelah dilakukan proses pengangkatan anak, 
maka anak angkat telah menjadi bagian dari keluarga angkatnya dan menetap untuk selamanya di lingkungan keluarga angkatnya.

Bertitik tolak dari keterangan yang telah dikemukakan di atas, maka dapat dipahami bahwa konsekuensi dari pengangkatan anak adalah anak angkat tersebut akan beralih kekerabatan ke dalam keluarga orang tua angkatnya. Kemudian akan terputus kekerabatannya dengan keluarga orang tau kandungnya.

\section{Anak Angkat Tidak Mendapat} Warisan Dari Orang Tua
Kandungnya

Walaupun anak angkat ini merupakan bagian atau keturunan dari orang tua kandungnya, tetapi kedudukannya sebagai ahli waris (orang yang akan memperoleh harta warisan) dari orang tua kandungnya akan dihapus. Sebab kebiasaan yang berlaku dalam masyarakat suku lembak, apabila ada anaknya yang berkeluarga, maka orang tua akan mempersiapkan harta, berupa kebun, sawah, atau lahan pertanian, untuk diberikan kepada anaknya yang baru berkeluarga tersebut. Jadi yang mempersiapkan anak angkat itu adalah orang tua angkatnya. ${ }^{29}$

\section{B. Kedudukan Sosial Anak Angkat Dalam Suku Lembak}

Sebagaimana diketahui bahwa salah satu akibat atau dampak dari pengangkatan anak pada suku lembak Kelurahan Dusun Besar, bahwa terjadinya perubahan status atau beralihnya kekerabatan anak angkat ke dalam keluarga orang tua angkatnya. Sehingga status dan kedudukan dalam masyarakat sama dengan anak kandung. Sehingga interaksi sosial dalam kehidupan masyarakat tidak ada perubahan sama sekali. Masyarakat sangat memaklumi tentang kedudukan anak angkat ini, karena telah melalui proses pengangkatan anak yang dipimpin oleh tokoh adat, maka masyarakat memandang kehadiran anak angkat ini setelah proses pengangkatan anak sampai ia dewasa adalah sama dengan anak kandung. Oleh karena itu tidak terlontar sedikitpun untuk menghina atau meremehkan anak angkat ini.

Dalam masyarakat suku lembak Kecamatan Dusun Besar kehadiran

29 Abu Bakar, Tokoh Adat, wawancara, tanggal 28 Mei 2015. 
Tinjauan Yuridis Kedudukan Anak Angkat dalam Sistem Kewarisan Hukum Adapt

Pada Suku Lembak

anak angkat tidak menjadi persoalan, dengan perkataan lain interaksinya dalam masyarakat telah diterima sebagai anak kandung. Sehingga dalam bergaul dan apabila upacara adat mereka akan diperlakukan sebagaimana halnya anak kandung.

\section{Tinjauan Secara $\quad$ Yuridis \\ Pengangkatan Anak Suku Lembak \\ Kelurahan Dusun Besar Kecamatan \\ Singaran Pati Kota Bengkulu \\ Berdasarkan Undang-Undang Nomor \\ 23 Tahun 2002 Tentang \\ Perlindungan Anak}

Adapun konsekuensi dari sistem pengangkatan anak yang dipraktekkan dalam masyarakat suku lembak Kelurahan Dusun Besar Kecamatan Singaran Pati Kota Bengkulu, maka kedudukan anak akan berposisi menggantikan anak kandung dalam segala hal pada lingkungan keluarga orang tua angkatnya. Dan juga akan menjadi bagian dari kekerabatan orang tua angkatnya, bahkan dalam kewarisan anak angkat ini mempunyai hak waris sama dengan anak kandung.

Sekarang ini mengenai pengaturan tentang pengangkatan anak sebagian diatur dalam Undang-Undang Nomor 23 Tahun 2002 tentang Perlindungan Anak, yaitu dirumuskan di dalam pasal 39, 40 dan 41 :

Pasal 39, berbunyi :

(1) Pengangkatan anak hanya dapat dilakukan untuk kepentingan yang terbaik bagi anak dan dilakukan berdasarkan adat kebiasaan setempat dan ketentuan peraturan perundangundangan yang berlaku.

(2) Pengangkatan anak sebagaimana dimaksud dalam ayat (1), tidak memutuskan hubungan darah antara anak yang diangkat dan orang tua kandungnya.

(3) Calon orang tua angkat harus seagama dengan agama yang dianut oleh calon anak angkat.

(4) Pengangkatan anak oleh warga negara asing hanya dapat dilakukan sebagai upaya terakhir.

(5) Dalam hal asal usul anak tidak diketahui, maka agama anak disesuaikan dengan agama mayoritas penduduk setempat.

Dalam pasal 40, berbunyi :

(1) Orang tua angkat wajib memberitahukan kepada anak angkatnya mengenai asal usulnya dan orang tua kandungnya.

(2) Pemberitahuan asal usul dan orang tua kandungnya sebagaimana dimaksud 
dalam ayat (1) dilakukan dengan memperhatikan kesiapan anak yang bersangkutan.

Dalam pasal 41 , berbunyi :

(1) Pemerintah melakukan dan bimbingan masyarakat pengawasan terhadap pelaksanaan pengangkatan anak.

(2) Ketentuan mengenai bimbingan dan pengawasan sebagaimana dimaksud dalam ayat (1) diatur dengan Peraturan Pemerintah.

Mencermati rumusan beberapa pasal di atas, maka dapat diketahui bahwa secara garis besarnya pelaksanaan pengangkatan anak yang terjadi pada masyarakat suku lembak Kelurahan Dusun Besar Kecamatan Singaran Pati Kota Bengkulu tidak sesuai dengan yang diatur dalam pasal 39 ayat (1) Undang-Undang Nomor 23 Tahun 2003 tentang Perlindungan Anak. Dimana pelaksanaan pengangkatan ini tersebut dilakukan menurut adat suku lembak dan hal ini telah digariskan oleh pasal 39 ayat (1) tersebut, tetapi yang belum sesuai dengan pasal 39 ayat (1) di atas adalah tujuan pengangkatan anak yang dilaksanakan oleh masyarakat suku lembak lebih mengutamakan untuk menyempurnakan dan menghilangkan rasa sepi pasangan suami isteri, dan bukan semata-mata untuk kepentingan yang terbaik bagi anak yang diangkat.

\section{PENUTUP \\ Kesimpulan}

Berdasarkan penjelasan yang telah dikemukakan di atas, dapat ditarik kesimpulan, yaitu sebagai berikut :

1. Proses pengangkatan anak menurut adat suku lembak Kelurahan Dusun Besar Kecamatan Singaran Pati Kota Bengkulu, yaitu sebagai berikut :

a. Tahap musyawarah

Tahap musyawarah itu terjadinya pembicaraan antara calon orang tua angkat dengan orang tua kandungnya, bahwa mereka akan membicarakan untuk melakukan pengangkatan ini. Pada tahap musyawarah ini akan terungkap apakah proses pengangkatan anak akan terjadi atau tidak.

b. Proses pengangkatan anak merupakan tahap kelanjutan dari tahap musyawarah, dimana antara calon orang tua angkat dengan orang tua kandung tercapai kata sepakat dan menyetujui terjadinya pengangkatan anak.

2. Penyebab pengangkatan anak pada masyarakat suku lembak, yaitu :

a. Mempertahankan keturunan. 
Tinjauan Yuridis Kedudukan Anak Angkat dalam Sistem Kewarisan Hukum Adapt

Pada Suku Lembak

b. Diharapkan anak angkat dapat menolong orang tua angkatnya di hari tua.

c. Karena hanya mempunyai anak tunggal.

d. Sebagai pemancing bagi suami isteri yang tidak mempunyai anak untuk mendapatkan anak kandung.

e. Karena tidak mempunyai anak lakilaki.

3. Dalam proses pengangkatan anak yang dilaksanakan dalam masyarakat suku lembak Kelurahan Dusun Besar Kecamatan Singaran Pati Kota Bengkulu, walaupun telah dilakukan melalui kebiasaan dan melibatkan tokoh adat, pemuka masyarakat. Tetapi proses pengangkatan anak tersebut tidak dilakukan melalui proses di Pengadilan Negeri, yaitu adanya penetapan dari hakim tentang kedudukan anak angkat itu. $\mathrm{Hal}$ ini berarti proses pengangkatan anak tersebut tidak sesuai dengan peraturan perundang-undangan.

\section{Saran-Saran}

1. Diharapkan kepada masyarakat suku lembak Kelurahan Dusun Besar Kecamatan Singaran Pati Kota Bengkulu, agar dalam melakukan pengangkatan ini benar-benar untuk kepentingan anak, bukan semata-mata hanya untuk menghilangkan rasa sepi dari orang tua angkatnya.
2. Diharapkan kepada masyarakat suku lembak Kelurahan Dusun Besar Kecamatan Singaran Pati Kota Bengkulu, agar dalam proses pengangkatan anak yang hanya dilakukan secara kebiasaan saja, diteruskan kepada proses pengangkatan melalui penetapan hakim di Pengadilan Negeri, agar anak angkat tersebut mempunyai bukti yang kuat bahwa ia merupakan anak angkat dari orang tua angkatnya.

3. Diharapkan kepada instansi yang berkepentingan agar dapat memberikan penerangan atau informasi kepada masyarakat, pada saat melakukan pengangkatan anak harus melibatkan pihak Pengadilan Negeri.

\section{DAFTAR PUSTAKA}

\section{Buku-Buku}

B2N Ter Haar, 1989. Asas-Asas dan Susunan Hukum Adat, Jakarta, Pradnya Paramita.

Bushar Muhammad, 1991. Pokok-Pokok Hukum Adat, Jakarta, Pradnya Paramita.

2001. Pokok-Pokok Hukum Adat. Jakarta, Pradnya Paramita.

C. Dewi Wulansari, 2010. Hukum Adat Indonesia. Bandung, Rafika Aditama.

Dewi Wulansari, 2010. Hukum Adat di Indonesia, Bandung, Rosda Karya.

Fatchur Rahman, 1991. Ilmu Waris, Surabaya, Al-Ikhlas. 


\section{P-ISSN : 2599-1892}

Volume : Vol. 1, No. 1, Januari 2018

Fuad Muhammad Fachrudin, 1995. Kedudukan Anak dan Masalahnya, Jakarta.

Hilman Hadikusuma, 2003. Hukum Perkawinan Adat, Bandung, Citra Aditya Bhakti.

Moh. Nazir, 1998. Metode Penelitian. Jakarta, Ghalia Indonesia.

Mudris Zaini, 2005, Adopsi Suatu Tinjauan Dari Tiga Sistem Hukum. Jakarta, Sinar Grafika.

Oemar Salim, 1997. Hukum Waris di Indonesia, Jakarta, Bumi Aksara.

R. Soepomo, 1991. Bab-Bab Tentang Hukum Adat, Jakarta, Bumi Aksara.

Soerjono Soekamto, 1997. Metode Penelitian Normatif. Jakarta, Sinar Grafika.

Soeroyo Wignyodiporo, 1993. Pengantar dan Asas-Asas Hukum Adat, Bandung, Rosda Karya.

WJS. Poerwadarminta, 1999. Kamus Besar Bahasa Indonesia. Jakarta, Balai Pustaka.

\section{Undang-Undang}

Undang-Undang Nomor 23 Tahun 2002 tentang Perlindungan Anak.

Internet

http://wid.widikipedia.org/wiki/suku.amarta. wordpress. 